\title{
The Common Agricultural Policy vis-à-vis European pastoralists: principles and practices
}

\author{
Silvia Nori and Michele Gemini
}

* Correspondence: mnori69@ominiverdi.com via casine, 10 - Firenze, Italy

\begin{abstract}
This article reviews how the European Union Common Agricultural Policy (CAP) currently addresses pastoralists' needs in Europe, and could further contribute to sustainable management of pastoral areas. The CAP provides a set of financial subsidies to farmers in the form of market, income and rural development support. We first present a brief overview of the CAP, its basic principles, the available instruments, recent developments and finally discuss the future challenges and potentials for pastoralists in the European Union.
\end{abstract}

Keywords: Common Agricultural Policy, European Union, pastoralism

\section{Introducing pastoralism and the Common Agricultural Policy}

Pastoralism is being increasingly appreciated worldwide as an environmentally friendly practice, which, in the European Union (EU) is valued as particularly important for the protection and the safeguarding of mountainous areas, defined as 'Europe's ecological backbone' (European Environment Agency 2010).

Appropriate pastoral resource management is recognised as favourable for the environment due to a number of reasons, which include:

- enhanced conservation of plant and animal biodiversity (UN 2010),

- sustainable land and water management by supporting the active management of vegetation cover reducing soil erosion, flooding and fire hazards, by facilitating water flow and retention, and

- important carbon sink capacities, since properly managed grasslands store approximately $34 \%$ of the global stock of $\mathrm{CO}_{2}$ ). If the grassland becomes degraded or is converted to cropland, it loses some of its capacity to store this carbon (FAO 2006;; WB, 2009).

Thus, pastoral resource management holds the potential to contribute to carbon sequestration, biodiversity protection and soil and water conservation by helping to maintain the grasslands - as also recognised by three UN Environmental Conventions biodiversity, desertification and climate change. In practice, matters are more controversial, as the scale, intensity and distribution of ecological impacts of an economic activity vary depending on differing physical, economic and social circumstances, on the decisions made by individual farmers and on the complexity of linkages between

(C) 2011 Nori and Gemini; licensee Springer. This is an Open Access article distributed under the terms of the Creative Commons Attribution License (http://creativecommons.org/licenses/by/2.0), which permits unrestricted use, distribution, and reproduction in any medium, provided the original work is properly cited. 
agricultural actions and environmental outcomes (EC 2006a). Experience attests that different dynamics in pastoral areas might give different environmental outcomes. For example, less intense land use and a certain degree of land abandonment in given areas can give rise to positive environmental impacts by reducing pressure on soil, air and water resources and increasing biodiversity. On the other hand, large reductions in grazing pressure or the complete cessation of grazing can give rise to changes in vegetation that result in reduced habitat and species diversity.

Extensive livestock systems and pastoralism represent increasingly interesting practices for the Common Agricultural Policy (CAP), the policy of the European Commission that promotes sustainable agriculture in a global environment through a number of support programmes as well as subsidy schemes. Since coming into operation, the overall aim of the CAP is to provide European farmers with a reasonable standard of living, consumers with quality food at fair prices and to maintain farming in all regions of the EU. The CAP represents an important financial engagement from the EU towards its countryside, and involves about $42 \%$ of the overall EU budget for 2011 (141.2 billion euros). There is little doubt that any other sector in the EU has received as much sustained support as agriculture since the end of World War II.

Since 1975, the designation of Less-Favoured Areas (LFAs) within the CAP recognises the specific features of areas presenting agro-ecological constraints (lack of water, climate, unfavourable soil and terrain characteristics, short crop season and tendencies of depopulation), including mountainous or hilly features. However, pastoralism in the EU is mostly associated with mountainous ecosystems areas which exist in southern as well as in northern Europe, where mobile livestock rearing is also practiced outside mountainous environments. LFAs benefit from different forms of compensatory allowances, i.e. the LFA payments - now called Natural Handicap Payments, and from a number of payments for structural adjustment. Such areas, indicated in the EU policy, are designated by national governments.

An important principle underpinning the CAP is that of subsidiarity, meaning that different institutional levels play diverse and complementary roles, and the central authority should have a subsidiary function, performing only those tasks which cannot be performed effectively at a more immediate or local level (typically the national and the regional levels). EU agricultural policy frames the general guidelines aimed at supporting and improving agricultural production - but then the detailed implementation of the scheme varies in different member countries of the EU. Within this framework, the extension and veterinary services addressing the needs and interests of livestock herders - pastoralists - are dealt with at national level.

\section{The design and functioning of the CAP}

In the recent decade, the CAP has undergone revisions and reforms, redesigning the framework regulating agricultural production and countryside management. Since the 2003 reform, more emphasis is allocated to environmental quality, food safety and animal welfare (Cooper et al. 2009). Through a principle named 'decoupling', EU funding support is partially detached from production (crop or livestock head) and instead towards promoting more environmentally friendly practices. Also in line with World Trade Organization (WTO) regulations, the aim of decoupling is to let the agricultural sector shift towards more market-based dynamics. Therefore, public financial support 
more directly relates to the proper stewardship of land and farmers' practices are remunerated for their capacity to deliver the basic public goods desired by European society.

According to these principles, the CAP is currently structured around two complementary pillars: the first pillar supports market measures and annual direct payments to farmers and is financed through annual payments from the budget of the EC. The second pillar supports farmers' initiatives and multi-annual rural development measures, which include environmental protection. The budget for these measures comes from programmes co-financed by the Member States. According to the principle of subsidiarity such measures are then differentially applied in the individual Member States.

The main aim of the first pillar through the direct payment scheme is to guarantee farmers more stable incomes, by providing remuneration related to the land area managed through farming practices; it is thus an area-based mechanism. For European pastoralists this means that they receive financial support related to the amount of the land they manage - rather than per head of animal kept, as it was the case until about 2003, when WTO regulations ruled out this arrangement. These mechanisms are intended to provide a basic level of support to maintain farming activity across the EU, to ensure a minimum level of maintenance to lands receiving payments, and to monitor and prevent significant declines in permanent pastures.

A main concern for European pastoralists in this pillar relates to the classification of land and thus their eligibility for CAP subsidy schemes. The Integrated Administration and Control System undertakes land categorisation and controls compliance with EU regulations. In order to benefit from CAP subsidies, a land area must be identified in the IACS system. Pastoralists' associations as well as environmental organisations claim that important portions of pastoral lands ${ }^{\mathrm{a}}$ are not classified as eligible for CAP payments and therefore the livestock owners who manage these lands cannot receive the relevant CAP support.

The current debate on CAP reform addresses the issue of better support targeting. Adaptations of the first pillar direct payment scheme should tackle the different economic and natural conditions that farmers are facing across the EU, which advocates for a more equitable distribution of direct financial support. What is envisaged is promotion of sustainable development of agriculture in areas with specific natural constraints, by providing farmers in such areas an additional, complementary income support in the form of an area-based payment.

The second pillar refers to measures pursuing the EU rural development policy and its implementing tool, the European Agricultural Fund for Rural Development. The objectives of this second pillar are in three main axes ${ }^{\mathrm{b}}$ through which financial resources are allocated.

1. Improving the competitiveness of the farm and forestry sector through support for restructuring, development and innovation.

2. Improvement of the environment and the countryside through support for land management as well as helping to fight climate change.

3. Improving the quality of life in rural areas and encouraging diversification of economic activity. 
Through the second axis of this pillar, farmers could receive compensation for sustainable land management, for instance, putting into practice agricultural activities that are more environmentally demanding than legally mandatory requirements. Typical instances for pastoralists include those of High Nature Value (HNV) areas, which mainly consist of semi-natural grasslands and are managed under farming systems characterised by low stocking densities, low levels of agro-chemical inputs and often labour intensive management practices such as shepherding. Examples of HNV farmland are alpine meadows and pasture. These low-intensity farming systems are associated with a high species and habitat diversity or the presence of species of European conservation concern (EC 2006a). These areas may benefit from payments that could either compensate for natural handicaps or remunerate for specific agro-environmental measures.

Evolving from the classification of Less-Favoured Areas, natural handicap payments in mountain areas and in other areas with handicaps contribute, through continued use of agricultural land, to maintaining the countryside as well as maintaining and promoting sustainable farming systems. These payments compensate for farmers' additional costs and income foregone related to permanent handicap for agricultural production in the area concerned. The annual payment for mountain areas is maximum $250 €$ per hectare; higher payments may be granted in certain areas in justified cases.

There is also remuneration for so-called agro-environmental measures. Agriculture and natural resource management are associated with a wide range of environmental public goods and services, many of which are highly valued by society. These range from agricultural landscapes to farmland biodiversity, to water quality, to soil functionality, to climate stability (i.e. carbon sequestration in the case of pastureland), to air quality, resilience to flooding, drought and fire - as well as a diverse suite of more social public goods, including farm animal welfare (Cooper et al. 2009). If valued, society must therefore provide economic incentives to encourage rural producers to divert their production systems from efficient production of farm commodities to the provision of such public goods, such as to restore or maintain specific habitats or to manage natural resources in a certain way which might imply extra cost, land use conflict or income forgone. In the case of pastoralists, such principles might well apply to livestock owners' genuine interest in preserving the environment and keeping it healthy.

Operationalizing such principles presents two challenges: (a) measuring the impact of certain practices and (b) linking the practice to a specific impact in the field, thus accounting for the potential effect of external impacts. In this regard, the discussion is currently upon enhancing the result-orientation of such measures. The current approach is based on monitoring effectiveness of a certain agricultural practice (e.g. preserving some specific plant species in wetland areas) in order to obtain a certain result, which is potentially beneficial to the environment (i.e. protect and/or regenerate a certain biotope). This approach implies higher transaction costs and does not directly provide a judgement of the effective impact on the environment.

An alternative approach that directly measures the impact on the environment (e.g. the degree of nesting of a certain bird species) is being debated as an option for the future. With this approach, measurement is simpler, but the overall assessment should 
also consider the incidence of external factors, thus resulting in a simpler but less reliable analysis.

In addition, in the axis of the second pillar, farmers receive a financial payment which compensates them for the respect of certain practices in protected sites in relation to the implementation of some Community policies (EC 2007,; 2009,; 2010a,; 2010b).

The Rural Development Policy also provides support through the 'LEADER' (Links Between Actions for the Development of the Rural Economy) approach, promoting the involvement of local public-private partnerships, supporting local action groups to design and carry out local development strategies and innovative activities for developing rural areas.

\section{Cases of EU rural development programmes for pastoral systems}

Some examples are provided to show how these measures are put into practice, accounting for the specificity of defined pastoral territories. In most cases, such schemes are tailored to traditional land use patterns and the specific local agro-ecological as well as socio-cultural conditions.

\section{Hexagone rural development programme - natural handicap compensation in mountain areas, France}

The Programme de Développement Rural Hexagone (2007 to 2013) (Government of France 2007) includes specific financial support to sheep transhumant systems that make use of mountainous resources. Such practices have a very important role in maintaining the rural environment but have to face practical difficulties tackling the natural handicap of mountainous territories and have to bear the costs associated with transporting the livestock to the mountains for seasonal grazing. There might be a number of economic drawbacks to such practices on a merely cost-benefit analysis.

The basic EU economic support due to natural handicap is increased in those cases when shepherds decide to undertake transhumant livestock movements. The increase is $10 \%$ for shepherds residing in mountainous areas and 30\% for those residing on the mountain 'piémont' (foothills), given the greater distance which has to be covered to reach the mountainous pastures.

\section{Agro-environmental measures for biodiversity in semi-natural grazing lands, Sweden}

In Sweden, a higher yearly livestock grazing density is required to preserve the specific biodiversity of mountain pasturelands situated in the Less-Favoured Areas (Government Offices of Sweden 2008). This involves a number of practices that are labour demanding and costly for the livestock owner. The grazing animals have to be on the mountain pastures during the whole grazing period, while the fodder value of seminatural grazing land is lower compared to arable (farmed) pasture, resulting in a reduced animal growth and thus an income forgone for the farmer. The subsidy received by the farmer aims in this situation to covers the costs for the reduced fodder value, for the additional grazing animals and for the longer grazing period required to fulfil the requirements.

Labour costs for transportation and surveillance of the animals are also taken into account. Animals must be transported up from the main farm to the mountain holding 
and the surrounding pastures in early summer and taken home again at the end of the season. Every day, the farmer must travel from their home farm to the mountain holding in order to keep an eye on the animals grazing on summer pastures; this cost of commuting to and from the holding is included in the calculation of the financial support.

Thus, the level of payment for mountain pastures is therefore based on the costs of managing the land according to biodiversity maintenance objectives - and includes remunerations to the livestock owner for the incurred costs or foregone income.

\section{Traditional livestock breeding scheme, Bulgaria}

The recent enlargement of the EU to the 12 new accession countries (Czech Republic, Estonia, Cyprus, Latvia, Lithuania, Hungary, Malta, Poland, Slovenia, Slovakia, Bulgaria and Romania) has somewhat contributed in reshaping the measures specifically addressing pastoral areas. In particular, Romania and Bulgaria contain significant land areas where pastoralism is a most important livelihood system, with degrees of subsistence (i.e. pastoral communities living directly on what they produce). Specific measures in these regions aim at enhancing the integration of pastoral communities into market dynamics, while still providing support to shepherding practices that are environmentally friendly.

In the example below (European Network for Rural Development 2010), the Bulgarian Rural Development Programme supports HNV extensive grazing systems through payments that compensate traditional mowing, and limiting livestock density.

This programme provides financial support to pastoralists that decide to rear animals of specified local traditional breeds, in danger of further decline in numbers and in some cases could be lost to farming, so to maintain biodiversity. Such practices are also incentivised in order to preserve genetic resources which are naturally adapted to the local and regional conditions; these have the potential to play an important role in maintaining traditional grazing systems in mountainous and semi-mountainous areas. The list of endangered breeds is defined, and includes cattle, buffalo, sheep, goat, swine and horses. EU support is provided only to animals which have a 'certificate of origin'. In this case, payment is made by livestock unit (LU). Payments per year per LU rates: cattle and buffalo - 200 EUR/LU; sheep and goats - 165 EUR/LU; swine - 122 EUR/LU; horse - 200 EUR/LU.

A pilot project initially addressing Pirin and Central Balkan National Parks supports traditional mountain pastoralism so that farmers can use customary seasonal grazing systems, involving shepherds looking after traditional local breeds in high mountain pastures in the summer months. This scheme also aims at promoting the use of Karakachan dogs as an efficient and environmentally friendly method of protecting grazing livestock from attack by large carnivores (wolves, bears, jackals and lynxes).

\section{Ox trail transnational cooperation project}

An example of a cross-border initiative that fits with pastoral concerns is the Ox Trail project (Projekt Oxenweg; http://www.oxenweg.net/) which aims at reviving the use as well as the culture associated with an ancient trail used by pastoralists that crosses central Europe. This trail was in use in the late Middle Ages to the early Modern Period to move oxen from Hungary and Transylvania to the west, to southern Germany. 
The revival of such route through a number of transnational projects aims to foster cultural communication between European regions and to encourage tourism. The programme is funded through the EU Leader programme, and involves partners from Hungary, Austria, Germany as well as from Romania and Slovakia. Pastoralism in such cases represents an added value for local development strategies.

\section{CAP reform and environmental goals relevant to pastoralists}

In order to respond to economic, environmental and territorial challenges, the three main objectives for the future CAP would be viable food production, sustainable management of natural resources and climate action and a balanced territorial development (8EC 2010c). In 2010, the Communication of the future of the Common Agricultural Policy was presented, as a basis for the new budgetary and legal framework for the CAP reform envisaged for 2013.

The reform intends to adapt by 'greening' direct payments, aiming to improve the environmental performance of the CAP. This objective could be reached through environmental actions such as permanent pasture, green cover, crop rotation and ecological set-aside. The requirements of Natura 2000 areas and improved elements of good agro-ecological conditions standards could also strengthen direct payments (EC 2006b,, 2010a). The provision of additional income support to farmers in areas with specific natural constraints as area-based payments helps to avoid land abandonment in marginal areas while providing public goods, and would be a measure in support of pastoralism.

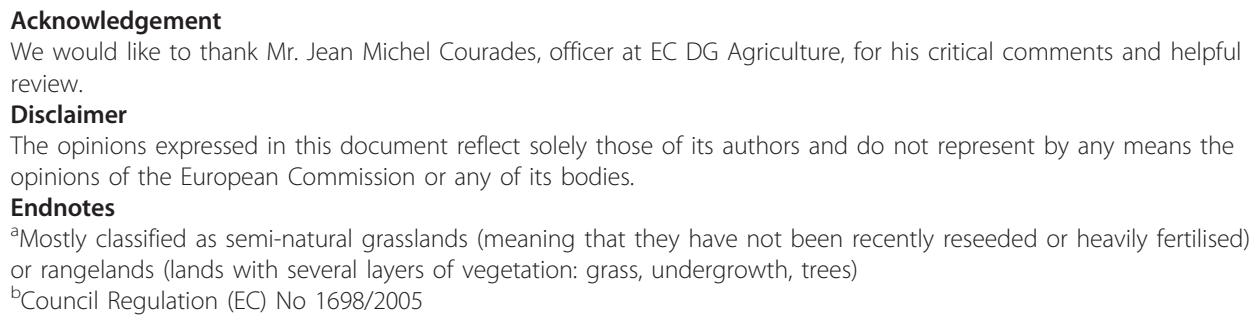


EC European Commission. 2010c. The CAP towards 2020: meeting the food, natural resources and territorial challenges of the future. Communication from the Commission to the European Parliament, the Council, the European Economic and Social Committee and the Committee of the Regions. http://ec.europa.eu/agriculture/cap-post-2013/communication/ com2010-672_en.pdf.

European Environment Agency EEA. 2010. Report No 6 Europe's ecological backbone: recognising the true value of our mountains. Office for Official Publications of the European Union. http://www.eea.europa.eu/publications/europesecological-backbone/.

European Network for Rural Development. 2010. Thematic working group 3. Public goods and public intervention. Final Report. http://enrd.ec.europa.eu/app_templates/filedownload.cfm?id=260BDAAE-0BDA-C671-41E7-31CED794278A.

FAO. 2006. Livestock's long shadow: environmental issues and options. Rome: UN Food and Agriculture Organization. ftp:// ftp.fao.org/docrep/fao/010/a0701e/a0701e.pdf.

Government of France. 2007. Programme de Développement Rural Hexagonal, 2007-2013. Ministère de l'Alimentation de I'Agriculture et de la Pêche. http://www.europe-en-france.gouv.fr/content/download/9385/60382/version/1/file/PDRH\% 2520Vdef.pdf.

Government Offices of Sweden. 2008. The European Agricultural Fund for Rural Development: Europe investing in rural areas. The Swedish Ministry of Agriculture Rural Development Programme for Sweden. Article no. Jo 08.008, Stockholm. http://www.regeringen.se/content/1/c6/08/27/31/de111eed.pdf.

UN. 2010. Convention on Biological Diversity. United Nations. http://www.cbd.int/.

World Bank. 2009. Minding the stock. Bringing public policy to bear on livestock sector development. Report No. 44010-GLB, Washington D.C: World Bank.

doi:10.1186/2041-7136-1-27

Cite this article as: Nori and Gemini: The Common Agricultural Policy vis-à-vis European pastoralists: principles and practices. Pastoralism: Research, Policy and Practice 2011 1:27.

\section{Submit your manuscript to a SpringerOpen ${ }^{\odot}$} journal and benefit from:

- Convenient online submission

- Rigorous peer review

- Immediate publication on acceptance

- Open access: articles freely available online

- High visibility within the field

- Retaining the copyright to your article

Submit your next manuscript at $\boldsymbol{s p r i n g e r o p e n . c o m ~}$ 